https://doi.org/10.5800/GT-2017-8-3-0280

\title{
DETRITAL ZIRCON AGES AND SOURCES OF MATERIAL FOR THE LOWER CAMBRIAN DEPOSITS OF THE MEL'GIN TROUGH OF THE BUREYA CONTINENTAL MASSIF
}

\author{
R. O. Ovchinnikov, A. A. Sorokin \\ Institute of Geology and Nature Management, Far East Branch of RAS, Blagoveshchensk, Russia
}

For citation: Ovchinnikov R.O., Sorokin A.A., 2017. Detrital zircon ages and sources of material for the Lower Cambrian deposits of the Mel'gin trough of the Bureya continental massif. Geodynamics \& Tectonophysics 8 (3), 525-527. doi:10.5800/GT-2017-8-3-0280.

Bureya continental massif is one of the largest continental massifs in the eastern part of the Central Asian orogenic belt (CAOB) (Fig. 1), and knowledge of its geological structure is of fundamental importance in understanding the history of its formation.

The 'basement' of the Bureya massif is commonly thought to be composed of metamorphic rocks of the Amur Group, which were, until recently, believed to be of Early Precambrian age [Krasny, Peng, 1999; Khanchuk, 2006]. However, U-Pb geochronological and Sm$\mathrm{Nd}$ isotopic studies of metasedimentary rocks of the Amur Group demonstrate that the protoliths of these metamorphic rocks were formed in the Late Proterozoic and/or Paleozoic, and they were most probably for- med in the Early Mesozoic. In addition, the juxtaposed metamorphic and structural transformations are associated with the Paleozoic and Mesozoic, but not with the Precambrian evolutionary episode of the CAOB [Kotov et al., 2009a, 2009b; Sal'nikova et al., 2013].

In this regard, age dating of the most ancient complexes in the structure of the Bureya massif is essential to understanding the history of its formation.

Here we report LA-ICP-MS U-Pb geochronological data for detrital zircons from the Lower Cambrian deposits of the Mel'gin trough. The geochronologic studies were conducted at the Arizona LaserChron Center (Analytical techniques see at https://sites.google.com/ a/laserchron.org/laserchron/home). 


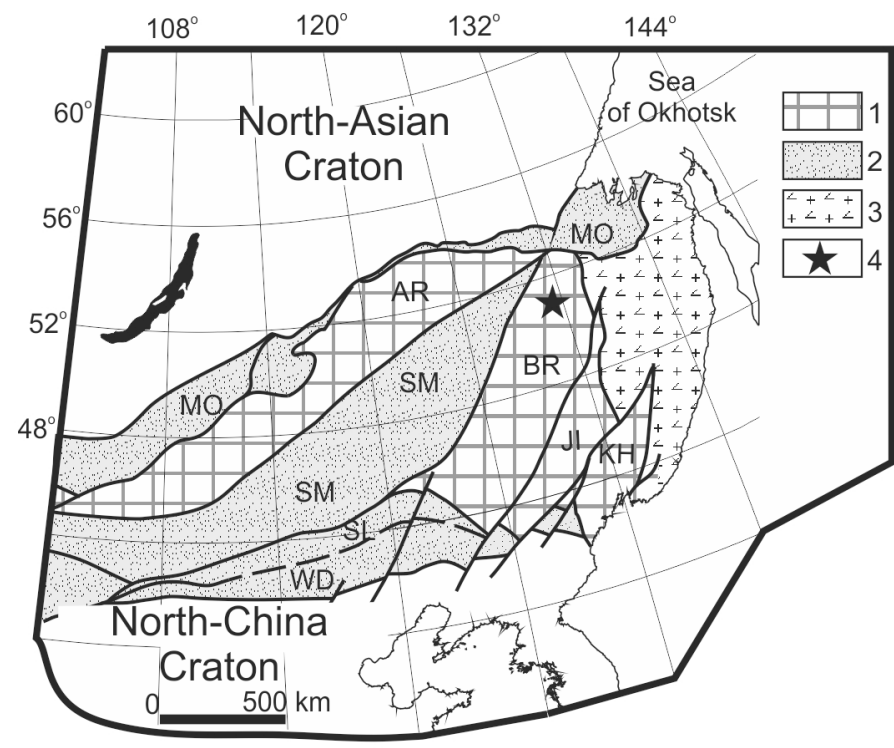

Fig. 1. Generalized structural scheme of the Eastern part of the Central Asian orogenic belt (modified from [Parfenov et al., 2003]).

1 - continental massifs (AR - Argun, BR - Bureya, JI - Jiamusi, KH- Khanka); 2 - Paleozoic-Early Mesozoic foldbelts (MO - Mongolian-Okhotsk, SM - South Mongolia, SL - Solonker, WD - Wenduermiao); 3 - Late Jurassic - Early Cretaceous orogenic belts; 4 the study area.

The Mel'gin trough is located in the central part of the Bureya massif and is formed by Vendian (Mel'gin Formation) and Lower Cambrian (Chergilen and Allin Formations) terrigenous-carbonate sediments.

The Mel'gin Formation, as much as 1000 m thick, is made up (according to [Petruk, Volkova, 2012]) of limestone, occasionally highly crystallized and dolomitic limestone, with beds of dolomite and interbeds of sandstone, phyllite shale, siltstone, mudstone, and phosphorite. Paniscollenia sp., Linella sp., and Venicularites sp. fossil remains were found in the Lower Mel'gin drainage basin, and Venicularites sp. was found on the Bureya left bank, suggesting a Vendian age of deposits [Petruk, Volkova, 2012].

The Chergilen Formation (according to [Petruk, Volkova, 2012]) consists of coaly-clay and calcareousclay shale, sericite and chert, siltstone, sandstone, and limestone. Limestones, conglomerates or gravelites are frequently found at the base of the 700-m-thick Chergilen Formation. The algae Epiphyton durum Korde occurring in limestone, Girwanella problematica Nich. and archeocyanates prints suggest a Lower Cambrian age of the Chergilen Formation [Petruk, Volkova, 2012].

The Allin Formation (according to [Petruk, Volkova, 2012]) totaling $600 \mathrm{~m}$ in thickness is formed essentially by sandstone interbedded with gravelstone and conglomerate, as well as by limestone lenses. Lower Cambrian fossil remains of Aldanocyathus sp., Coscinocyathus sp., and Bija sibirica Masl. were found in the limestone [Petruk, Volkova, 2012].

There was no discordance in age for 118 of $130 \mathrm{de}-$ trital zircon grains from the siltstone of the Chergilen Formation (sample K-30-1). These zircons are mostly Late Riphean (36\%, peak at $2935 \mathrm{Ma}$ ) and Early Riphean $(27 \%$, peak at $\sim 1.4 \mathrm{Ga})$ in age (Fig. $2, a)$. The Middle Riphean (19\%) and Lower Proterozoic (14\%) zircons are subordinate and do not form distinct peaks on the histogram, and the Archean zircons are represented by single grains (3\%).

A total of 82 of 115 detrital zircon grains from the siltstone of the Allin Formation (sample 101929) yielded concordant ages. Late Riphean zircons are most
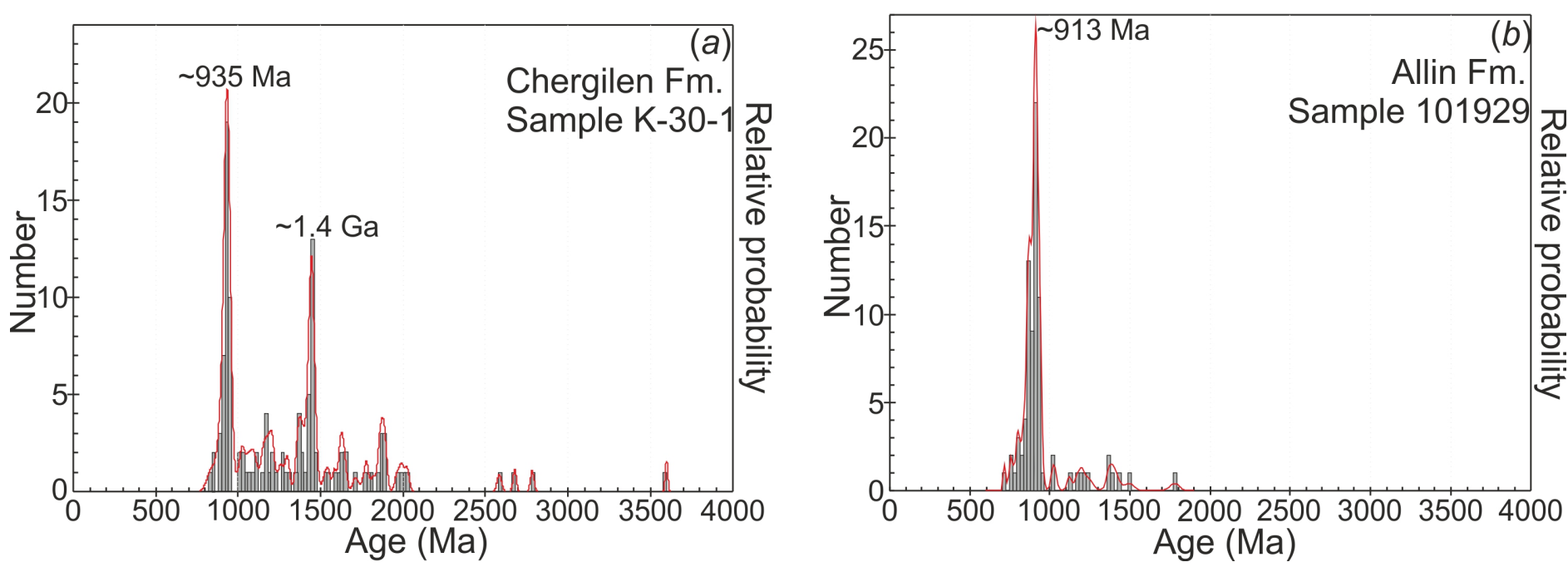

Fig. 2. Histograms and relative probability plots of ages of detrital zircons from siltstone of the: $a$ - Chergilen Formation (sample K-30-1) and $b$-siltstone of the Allin Formation (sample 101929). 
abundant (87\%, peak at $~ 913$ Ma) (Fig. 2, b), and zircon grains of Middle Riphean (6\%), Early Riphean $(6 \%)$ and Early Proterozoic $(1 \%)$ ages are subordinate.

According to the research findings, Late Riphean zircons (peaks on the plots at $\sim 935 \mathrm{Ma}$ and $\sim 913 \mathrm{Ma}$ ) are clearly dominant among the detrital zircons from siltstones of the Chergilen and Allin Formations of the Mel'gin trough of the Bureya massif. Late Riphean intrusions of the gabbro and granite, which have been recently identified in the structure of the massif based on the geochronological data, appear to be their source [Sorokin et al., 2016]. The question of source rocks for zircons of an older age is to be answered. The reason for this is the lack of reliable data on pre-Late Riphean intrusions in the structure of the Bureya massif, as well as the nearby Jiamusi massif (see reviews in [Wu et al., 2011]).

Acknowledgements. This study was supported by the Russian Foundation for Basic Research (project No. 17-55-53005).

\section{REFERENCES}

Khanchuk A.I. (Ed.), 2006. Geodynamics, Magmatism, and Metallogeny of Eastern Russia. Book 1. Dal'nauka, Vladivostok, 572 p.(in Russian).

Kotov A.B., Sorokin A.A., Sal'nikova E.B., Sorokin A.P., Velikoslavinskii S.D., Anisimova I.V., Yakovleva S.Z., 2009a. Early Paleozoic age of gabbroids of the Amur complex (Bureya-Jiamusi superterrane of the Central Asian Fold Belt). Doklady Earth Sciences 425 (1), 185-188. https://doi.org/10.1134/S1028334X09020019.

Kotov A.B., Velikoslavinskii S.D., Sorokin A.A., Kotova L.N., Sorokin A.P., Larin A.M., Kovach V.P., Zagornaya N.Yu., Kurguzova A.V., 2009b. Age of the Amur group of the Bureya-Jiamusi Superterrane in the Central Asian fold belt: Sm-Nd isotope evidence. Doklady Earth Sciences 429 (8), 1245-1248. https://doi.org/10.1134/S1028334X09080029.

Krasny L.I., Peng Y. (Eds-in-Chief), 1999. Geological Map of the Amur Region and Adjacent Areas, Scale 1:2500000. VSEGEI, St. Petersburg (in Russian).

Parfenov L.M., Berzin N.A., Khanchuk A.I., Badarch G., Belichenko V.G., Bulgatov A.N., Dril' S.I., Kirillova G.L., Kuz'min M.I., Nokleberg W., Prokop'ev A.V., Timofeev V.F., Tomurtogoo O., Yan H., 2003. A model for the formation of orogenic belts of Central and Northeast Asia. Tikhookeanskaya Geologiya 22 (6), 7-41 (in Russian).

Petruk N.N., Volkova Yu.R., 2012. State Geological Map of the Russian Federation 1:1000000, Ser. Far-Eastern, Sheet no. M-52. A.P. Karpinsky Russian Geological Research Institute, St. Petersburg.

Sal'nikova E.B., Kotov A.B., Kovach V.P., Velikoslavinskii S.D., Jahn B.-M., Sorokin A.A., Sorokin A.P., Wang K.-L., Chan S.-L., Li H.-Ya., Tolmacheva E.V., 2013. Mesozoic age of the Uril formation of the Amur group, Lesser Khingan terrane of the Central Asian Foldbelt: results of $\mathrm{U}-\mathrm{Pb}$ and Lu-Hf isotopic studies of detrital zircons. Doklady Earth Sciences 453 (2), 1181-1184. https://doi.org/10.1134/S1028334X13120076.

Sorokin A.A., Ovchinnikov R.O., Kudryashov N.M., Sorokin A.P., 2016. An Early Neoproterozoic gabbro-granite association in the Bureya continental massif (Central Asian Fold Belt): first geochemical and geochronological data. Doklady Earth Sciences 471 (2), 1307-1311. https://doi.org/10.1134/S1028334X16120230.

Wu F.Y., Sun D.Y., Ge W.C., 2011. Geochronology of the Phanerozoic granitoids in northeastern China. Journal of Asian Earth Sciences 41 (1), 1-30.https://doi.org/10.1016/j.jseaes.2010.11.014. 